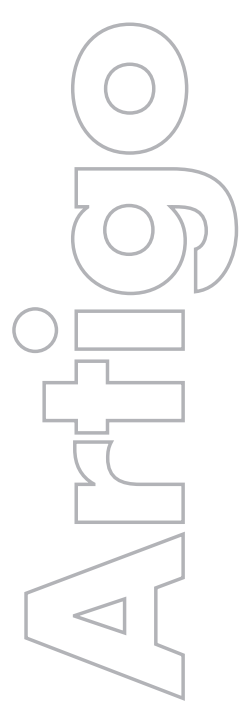

revista

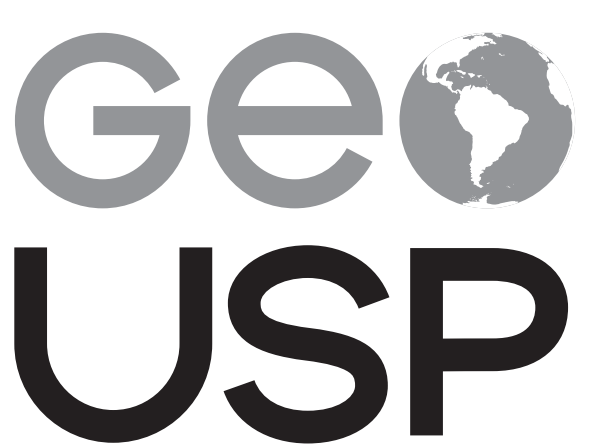

espaço e tempo

Volume $19 \cdot n^{\circ} 3$ (2015)

\section{A espacialização dos sistemas atmosféricos e a análise rítmica para o centro-sul do Brasil}

\author{
Victor da Assunção Borsato \\ UEM-Nupelia \\ Francisco de Assis Mendonça \\ UFPR \\ p. $585-604$
}

Como citar este artigo:

BORSATO, V. A.; MENDONÇA, F. A. A espacialização dos sistemas atmosféricos e a análise rítmica para o CentroSul do Brasil. Geousp - Espaço e Tempo (Online), v. 19, n. 3, p. 585-604, mês. 2016. ISSN 2179-0892.

Disponível em: URL: http://www.revistas.usp.br/geousp/ article/view/107613. DOI: http://dx.doi.org/10.11606/ issn.2179-0892.geousp.2015.107613.

\section{(c) $)$}

Este artigo está licenciado sob a Creative Commons Attribution 4.0 License. 


\title{
A espacialização dos sistemas atmosféricos e a análise rítmica para o centro-sul do Brasil
}

\section{Resumo}

objetivo do estudo foi quantificar e qualificar a espacialização temporal e a evolução dos sistemas atmosféricos para o Centro-Sul do Brasil, por meio da análise rítmica, a partir de quatro localidades, no mês de julho de 2015: Campo Mourão-PR, Cáceres-MT, Brasília-DF e Caparaó-MG. Julho é um mês característico da estação do inverno, e 2005, ano neutro, considerando o El Niño e a La Niña. Na estação do inverno, a dinâmica atmosférica para essa região é comandada basicamente pelas massas de ar polar atlântica, tropical atlântica, tropical continental e sistema frontal. A massa tropical continental atua limitadamente a partir do oeste da região. Os principais episódios de chuva foram frontais, e a altura decresce do sul para o norte. Como essa região não é o centro de origem de nenhum sistema atmosférico, ela se caracteriza como uma região terminal ou dissipatória, ou seja, onde as massas de ar se modificam. Por essa razão, todos os sistemas que atuam, modificam-se à medida que avançam, assim como diminui sua participação cronológica no estado do tempo.

Palavras-chave: Climatologia Geográfica. Ritmo. Dinâmica atmosférica. Massas de ar.

\section{Spatialization of atmospheric systems and rhythmic analysis for Brazil's south center}

\begin{abstract}
This study aimed at quantifying and qualifying the weather spatialization and the evolution of atmospheric systems for Brazil's South Center, through Rhythmic Analysis, from four locations: Campo Mourão-PR, Cáceres-MT, Brasilia-DF and Caparaó-MG. The chosen month was July 2005. July is a characteristic month of the winter season, and 2005, a neutral year, considering El Niño and La Niña. The atmospheric dynamics for this region, in the winter season, is basically controlled by the Atlantic Polar, the Atlantic Tropical, and the continental Tropical air masses, and by the frontal system.
\end{abstract}


The continental Tropical mass acts limitedly from the west of the region. The main rainfall episodes were frontal, and the height decreases from south to north. As this region is not the center of origin of any atmospheric system, it is characterized as a terminal region or sink, that is, where the air masses are modified. For this reason, all systems in operation are modified as they advance, as well as the chronological participation in the state of weather decreases.

Keywords: Geographical Climatology. Rhythm. Atmospheric dynamics. Air masses.

\section{Introdução}

Centro-Sul do Brasil é uma macrorregião que se estende pelo Sul, Sudeste, Centro-Oeste e extremo sul do Nordeste. Climatologicamente, é uma região de transição climática. Essa grande região é fortemente influenciada pelo oceano Atlântico, pela continentalidade e também pela grande extensão latitudinal.

Segundo Nimer (1966), o estudo das massas de ar que constitui os princípios básicos da climatologia dinâmica, deve focar o estudo da circulação atmosférica. Sugere ainda que se estude a frequência de cada massa de ar em porcentagem do tempo em que cada uma está presente sobre a região, levando em conta também a estacionalidade.

Considerando a dinâmica dos sistemas atmosféricos, o Centro-Sul do Brasil é dominado por quatro massas de ar e pelo sistema frontal. Todas as massas de ar avançam a partir dos seus centros de origem e impõem suas características. Por essa razão, o sul dessa grande região é fortemente influenciado pela massa polar e pelos sistemas frontais; o oeste é mais influenciado pelos sistemas continentais; e o leste, pelo sistema oceânico.

É importante observar que o Centro-Sul do Brasil não é palco de origem de qualquer centro de ação dos sistemas atmosféricos, ou seja, essa região não dá origem a qualquer sistema atmosférico. Por isso, ela se constitui em uma região de dissipação, modificação ou total descaracterização dos sistemas que avançam a partir dos seus centros de origens.

Essas condições implicam uma diversidade de tipos de tempo. É possível de se observar, num mesmo momento, a atuação de até quatro sistemas. No sul, a massa polar avançando; na altura do trópico de Capricórnio, o sistema frontal; em um dos seus estágios, no oeste, Mato Grosso, a atuação da massa tropical continental; e no leste, São Paulo, Rio de Janeiro e Minas Gerais, a influência da massa tropical atlântica. Todos esses sistemas apresentam características próprias que se modificam à medida que avançam e assimilam as características das áreas percorridas.

Nessa escala de abordagem, as características locais respondem aos sistemas, ora como elementos que facilitam a propagação, ora oferecendo mais resistência. As propriedades dos sistemas, a estacionalidade e as características geográfica das localidades determinam a intensidade das modificações. 
Para a estação do verão, o intenso aquecimento continental favorece a expansão das massas de ar de baixa pressão. Por outro lado, na estação do inverno, o tímido aquecimento continental favorece os avanços dos sistemas de alta pressão. Mesmo assimilando as características por onde se deslocam, suas modificações são mais lentas no tempo, possibilitando percorrer mais áreas. Por isso, no inverno, é possível que a massa polar atlântica, sistema de alta pressão e temperaturas amenas, avance até a Amazônia, causando o fenômeno da friagem (Serra; Ratisbonna, 1945).

Inferimos também que, na circulação geral, há deslocamento sazonal da Zona de Convergências Intertropical. As grandes células também se deslocam acompanhando o movimento estacional. De acordo com a estação do ano, os centros barométricos de origem dinâmica sofrem pequenas oscilações, para o sul no verão, e para o norte no inverno, para o hemisfério sul. Também conforme a estação do ano, sobre os continentes, as altas pressões de origem térmica, comuns no inverno, dão lugar às baixas pressões térmicas do verão.

Considerando todas essas observações, traçamos como objetivo principal acompanhar e qualificar a evolução dos sistemas atmosféricos por meio da análise rítmica a partir de quatro localidades: Campo Mourão-PR, Cáceres-MT, Brasília-DF e Caparaó-MG (Figura 1). Localidade, porque para a análise, consideram-se os dados dos elementos do tempo da estação, por isso local. Para a leitura das cartas, o local é o referencial, considerando que os sistemas são sinóticos, ou seja, na escala regional.

A análise rítmica, metodologia desenvolvida pelo professor Carlos Augusto de Figueiredo Monteiro (1971), permite a identificação dos tipos de tempo gerado por cada sistema atmosférico, assim como acompanhar a sua evolução, da gênese à dissipação, considerando que o ritmo climático "exige decomposição cronológica já que os estados atmosféricos, em contínua sucessão, produzem-se em unidades bem menores" (Monteiro, 1971, p. 9).

Este artigo é um recorte do projeto A Dinâmica Climática no Centro-Sul do Brasil para a Série Histórica 2000 a 2010.

A análise rítmica foi feita para julho de 2005, porque, na série 2000-2010, foi o ano que se apresentou neutro, considerando as anomalias causadas pelos fenômenos El Niño e La Niña, bastante ativos nessa década. Julho é um mês de inverno.

\section{Metodologia}

Na Climatologia Geográfica, adota-se a concepção dinâmica de clima, proposta por Sorre (1951), ajustada à análise rítmica, desenvolvida por Monteiro (1971), na qual o autor sugere o estudo das variações diárias dos elementos climáticos, associadas à circulação sinótica, de modo a revelar a gênese dos fenômenos climáticos.

Os sistemas atmosféricos foram quantificados a partir da leitura e interpretação das cartas sinóticas da Marinha do Brasil, metodologia proposta por Pédelaborde (1970), e nas técnicas desenvolvidas por Borsato (2008). As imagens de satélite no canal infravermelho foram utilizadas como suporte para a identificação do sistema atuante. 
Figura 1 - Localização da área de estudo. Esboço da macrorregião Centro-Sul do Brasil e a localização de Campo Mourão-PR, Cáceres-MT, Brasília-DF e Caparaó-MG

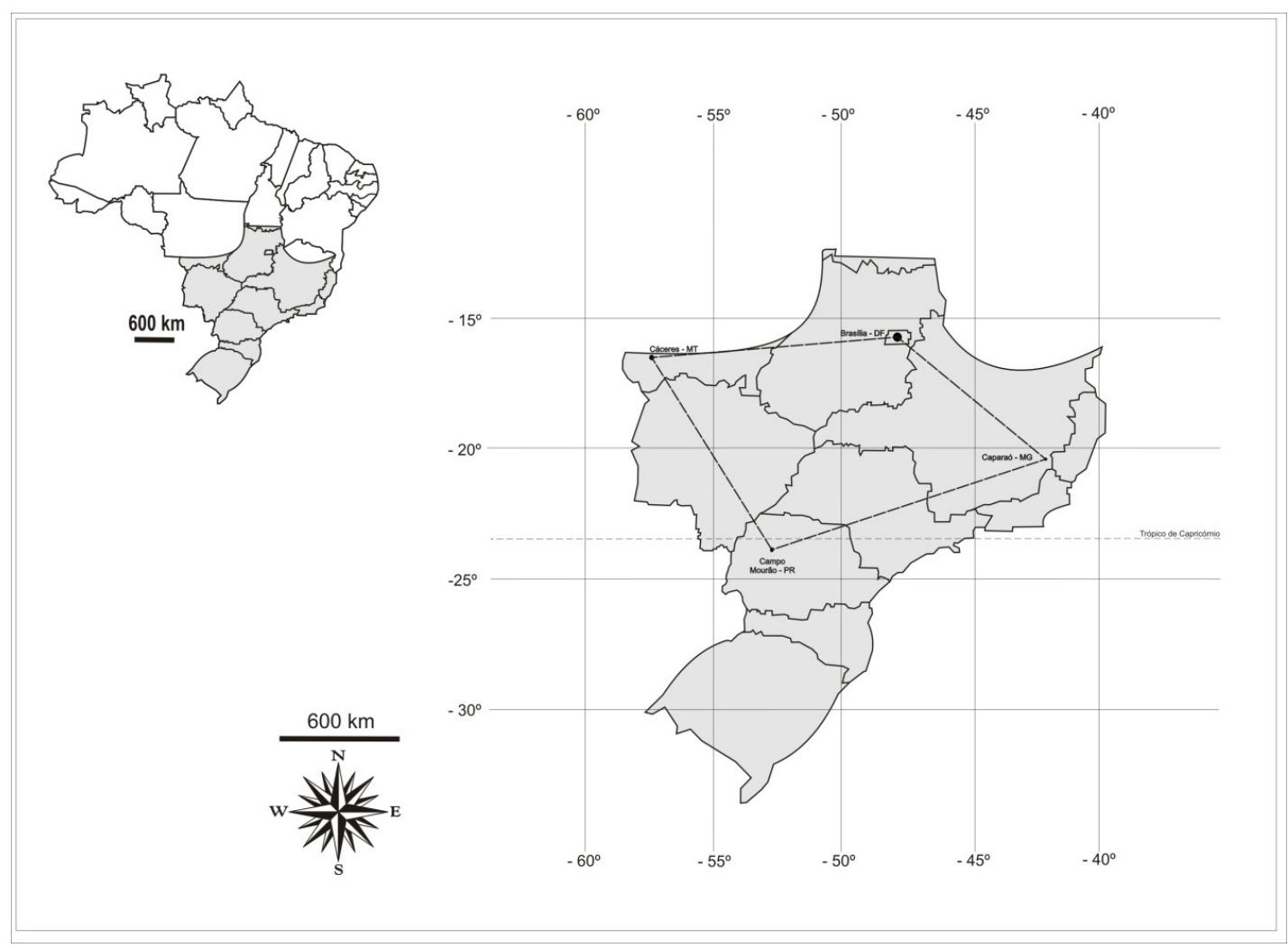

organização: Os autores.

Os sistemas atmosféricos considerados foram aqueles que atuaram no Centro-Sul do Brasil, ou seja: Sistema Frontal (SF), massa tropical continental (mTc), massa tropical atlântica (mTa), massa polar atlântica (mPa) e massa Equatorial continental (mEc) (Vianello, 2000; Varejão-Silva, 2000; Ferreira, 1989; Oliveira; Vianello; Ferreira, 2001; Biscaro, 2007).

Para o registro dos sistemas atmosféricos, foram elaboradas tabelas em planilha do Excel. Atribuiu-se valores numéricos (24) para o dia em que um único sistema atuou na região, e às vezes (12) para cada um, quando a região esteve sob a confluência de dois sistemas, ou valores diferentes, a julgar pelo tempo de participação. Os valores mensais ou para as estações foram considerados em porcentagens, e estas, por sua vez, em histogramas e cartogramas.

A pressão atmosférica lida nas cartas sinóticas da Marinha do Brasil foi considerada pressão baixa quando aquém de $1.013 \mathrm{hPa}$, e alta quando acima desse valor. Para esta pesquisa, a mTc foi considerada atuante somente sob as condições de pressão baixa. Considerou-se também a configuração da célula ciclonal sobre a região de origem, Planície do Chaco.

As porcentagens das participações dos sistemas atmosféricos foram especializadas em cartogramas por meio do Sistema de Informação Geográfica Sufer 7, programa de computador especial para representar o relevo, embora ele apresente um aplicativo que permite que o relevo seja representado através de isolinhas, as quais, para esse caso, representaram as porcentagens das participações dos sistemas atmosféricos. 
Para verificar a participação da mPa no estado do tempo, usou-se um recorte do mapa do Brasil, com destaque para o Centro-Sul e ao norte do trópico de Capricórnio, limitando-se ao norte com o paralelo - $15^{\circ}$. A partir desse mapa esboço, foram plotadas as isolinhas, as quais mostram a distribuição espacial por meio das porcentagens da participação da mPa no estado do tempo.

A análise rítmica foi executada nos moldes da proposta de Monteiro (1971), ajustada ao programa computacional RitmoAnalise (Borsato, 2006), executada para julho de 2005.

\section{Análise dos resultados}

Em julho, considerando os ângulos de incidência da luz solar, o Sol encontra-se sobre o hemisfério norte, proporcionando para o Centro-Sul do Brasil as menores taxas de aquecimento, considerando a diminuição do ângulo de incidência da luz e do fotoperíodo. Esse menor aquecimento favorece a ampliação e o domínio dos sistemas de alta pressão.

\section{Dinâmica dos sistemas atmosféricos}

No mês de julho, aturam na região Centro-Sul do Brasil, a mTa, a mPa, a mTc e os sistemas frontais. A mEc e a zona de convergência do Atlântico Sul (ZCAS) não se manifestaram na região neste mês.

A dinâmica dos sistemas atmosféricos mostrou um amplo predomínio dos sistemas de alta pressão. Aquele que mais tempo cronológico atuou foi a mTa. Como seu centro de ação encontra-se no Atlântico Sul, e a manifestação se dá a partir de cristas que se lançam para o interior do Brasil, as manifestações no estado do tempo são persistentes e não geradoras de alterações bruscas no estado do tempo atmosférico.

A mTa é um sistema anticiclonal. Os anticiclones são centros de alta pressão atmosférica. Esses sistemas se distinguem por terem um padrão de circulação de subsidência e divergência de ar na superfície (convergência na alta troposfera). Tais características resultam em condições de tempo nas quais predominam estabilidade atmosférica, céu limpo e baixa umidade (Musk, 1988).

Sant' anna Neto (1990) destaca que a atuação do Anticiclone Subtropical entre o oceano e o continente apresenta, para o leste da região, as seguintes características: umidade mais ou menos alta, em superfície, pressões relativamente elevadas e constantes, além de ventos geralmente de leste e nordeste. No interior, ele se encontra continentalizado, decorrente do avanço sobre o continente, e caracteriza-se por apresentar temperaturas elevadas, baixa umidade relativa do ar e pressões inferiores às de sua face oceânica.

O centro formador da $\mathrm{mTa}$ é a alta subtropical do Atlântico Sul (Asas), que se localiza entre as coordenadas $-10^{\circ}$ e $-20^{\circ}$ de longitude e $-20^{\circ}$ e $-40^{\circ}$ de latitude:

Alta do Atlântico Sul - Durante todo o ano nas regiões tropicais e temperadas do Brasil, à exceção do oeste da Amazônia e do Centro-Oeste do Brasil, sopram ventos de SE a NE, oriundos das altas pressões subtropicais, ou seja, do anticiclone semifixo do Atlântico Sul. 
Este anticiclone, que constitui a massa de ar tropical marítima, possui geralmente temperaturas elevadas, ou amenas, fornecidas pela intensa radiação solar e telúrica das latitudes tropicais e forte umidade específica, fornecida pela intensa evaporação marítima. Entretanto, em virtude de sua constante subsidência superior e consequente inversão de temperatura, sua umidade é limitada à camada superficial, o que lhe dá um caráter de homogeneidade e estabilidade [...] (Nimer, 1971, p. 10).

Para a série estudada, verificou-se que a mTa tem importância fundamental no estado do tempo e na determinação do ritmo climático em toda essa grande região. Ela participa ativamente e mais intensamente no inverno, período em que o centro de ação se intensifica e se aproxima do continente:

$[\ldots .$.$] estes anticiclones ora se afastam para o oceano ora invadem parcialmente o$ continente. Da mesma forma, eles oscilam em latitude e pressão, mais ou menos da seguinte maneira: quanto à pressão, em janeiro (mês representativo do solstício de verão do hemisfério sul), o núcleo central destes anticiclones possui cerca de $1.018 \mathrm{mb}$, em média, enquanto em julho (mês representativo do solstício de inverno no hemisfério sul) seu núcleo possui em média cerca de 1.024 mb; quanto à posição latitudinal média, estes anticiclones apresentam ligeira diferença, uma vez que, em janeiro a alta do Pacífico possui posição média em torno de $32 \circ$ lat., enquanto a alta do Atlântico situa-se em torno de $28^{\circ}$ lat., em janeiro e $23 \circ$ lat., em julho cerca de $26^{\circ}$ lat. Enquanto a alta do Atlântico situa-se em torno de $28^{\circ}$ lat. Em janeiro e 230 lat. Em julho [...] (Nimer, 1971, p. 10)

A região de Brasília foi a que mais tempo cronológico esteve sob a atuação da mTa: 84,4\%, seguida por Caparaó, com 45,2\%, por Campo Mourão, com 25,8\%, e, finalmente, por Cáceres, com apenas 21,0\%. A Figura 2 mostra a espacialização desse sistema para o Centro-Sul do Brasil.

As cartas sinóticas mostram que os ventos de superfície ao contornar o centro anticiclônico da Alta do Atlântico, avançam para o interior do continente pelo litoral sul do Nordeste do Brasil, por isso, a região de Brasília teve mais participação do que qualquer outra região do Centro-Sul do Brasil para julho. Considerando a estação do inverno, o resultado é outro. Borsato e Mendonça (2012) estudaram a espacialização da mTa no Centro-Sul do Brasil para o período de 2002 a 2010 e a região de Caparaó foi a que teve mais participação no estado do tempo:

Com relação à espacialização do sistema, houve uma grande variabilidade. A mTa é o principal sistema atmosférico em Caparaó, considerando apenas o tempo de atuação 38,6\%. A atuação diminui para o interior, e em Brasília cai para 25,1\%, para 8,7\% em Campo Mourão e, finalmente, para apenas 3,2\% em Cáceres (Borsato; Mendonça, 2012). 
Figura 2 - Esboço do mapa da macrorregião Centro-Sul do Brasil. As isolinhas indicam a porcentagem da participação da mTa para o mês de julho de 2005

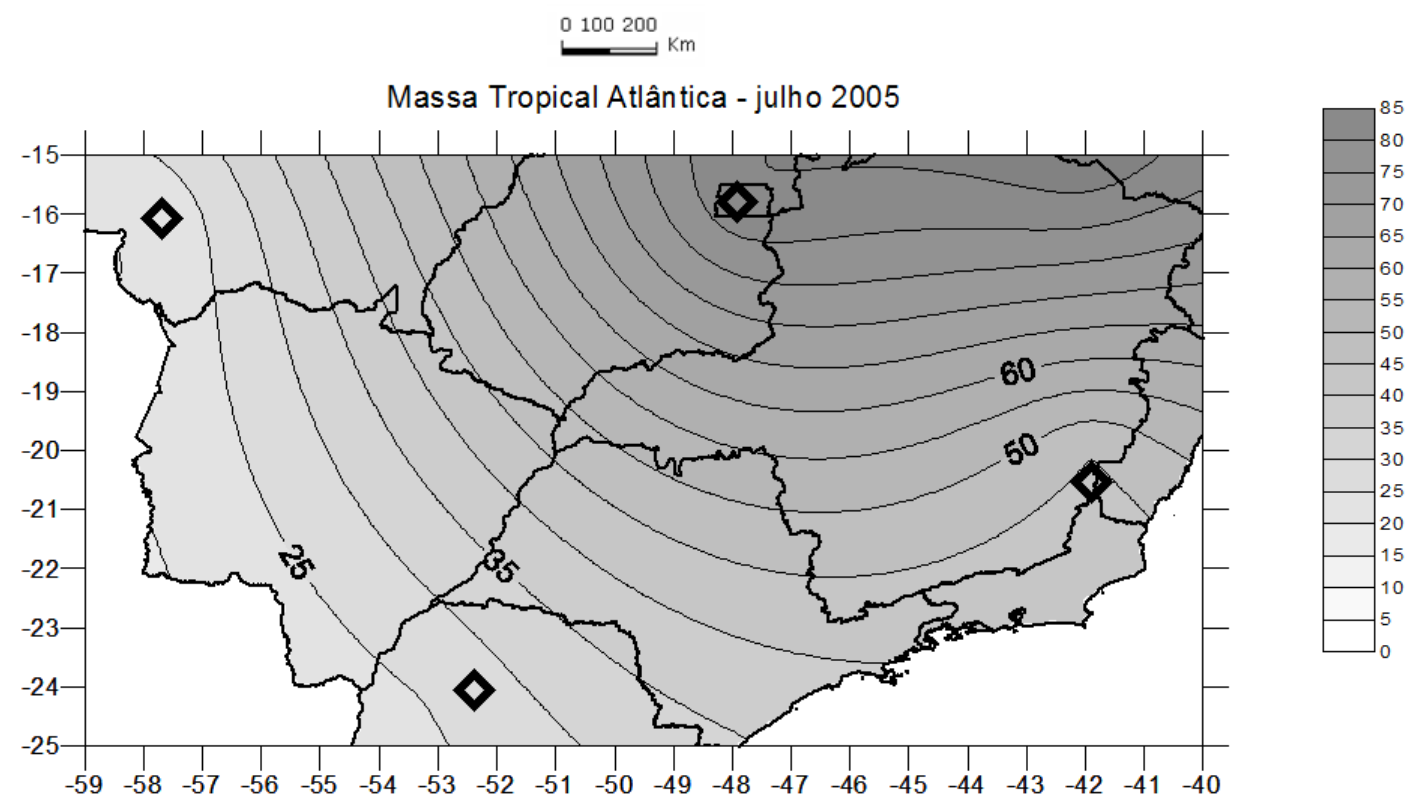

organização: Os autores.

O segundo sistema que mais tempo cronológico atuou foi a $\mathrm{mPa}$, sistema de alta pressão. Uma das características marcantes desse sistema é a onda de frio, consequência do seu avanço para o interior do continente. À medida que ela avança para o norte, modifica-se e se desintensifica, por isso as mudanças na temperatura não são pronunciadas depois da linha do trópico de Capricórnio:

A friagem aparece geralmente no inverno, isto é, no período de abril a outubro. Nessa época do ano, os dois anticiclones semifixos, além de ocuparem uma posição mais setentrional, se estendem sobre o continente. Esse fato é mais acentuado para o centro do Atlântico, deslocando-se assim para oeste a passagem entre as duas células. No interior, no solo, as calmarias facilitam o caminho da massa, contrariamente ao que sucede no verão, em que, como já vimos, sopram os ventos de $\mathrm{N}$ a NW aspirados pela baixa continental. Devemos lembrar ainda que sobre a última, existe nessa época do ano um anticiclone superior, cujos ventos de SW tendem a conduzir as altas móveis para o litoral do Atlântico, impedindo ao mesmo tempo as trajetórias pelo continente onde os ventos em altitude são de NW (Serra; Ratisbonna, 1945, p. 174).

Nos meses mais frios, a mPa pode avançar até a linha do equador, e causar na Amazônia o fenômeno da friagem (Serra; Ratisbonna, 1945). Para a região de Campo Mourão, nessas ocasiões, a onda de frio é intensa e pode causar o fenômeno das geadas noturnas. No período estudado, não foi contabilizado o número de sistemas que avançaram até a Amazônia. 
A participação da mPa decresce para o norte, no tempo de atuação e na intensidade. Por essa razão, a maior participação é para a região de Campo Mourão. Em julho de 2005, foi de 53,2\%. A segunda localidade com mais participação foi Caparaó, 48,4\%. Para Cáceres, a participação foi de 40,3\%, e Brasília, 14,5\% (Figura 3).

Na zona de contato entre a massa polar e as continentalizadas, forma-se uma zona de contato com características higrotérmicas distintas, por isso elas não se misturam e formam um front.

No Brasil, os sistemas frontais avançam a partir do sul, no sentido sudoeste- nordeste, e frequentemente ultrapassam a linha do trópico de Capricórnio. $\bigcirc$ Sul do Brasil também é uma região de frontogênese, ou seja, em determinadas condições, há sobre a região a evolução dos ciclogênese: "Ciclogênese é o processo de abaixamento da pressão atmosférica de superfície com consequente formação de circulação ciclônica" (Ferreira, 1989). Segundo os autores, na América do Sul e Atlântico Sul (até 30 W), metade das ciclogêneses acontecem ao norte de $35^{\circ} \mathrm{S}$; a maior frequência de ciclogênese ocorre sobre o oceano no verão e sobre o continente no inverno.

\section{Figura 3 - Esboço do mapa da macrorregião Centro-Sul do Brasil. As isolinhas indicam a porcentagem da participação da $\mathrm{mPa}$ para o mês de julho de 2005}

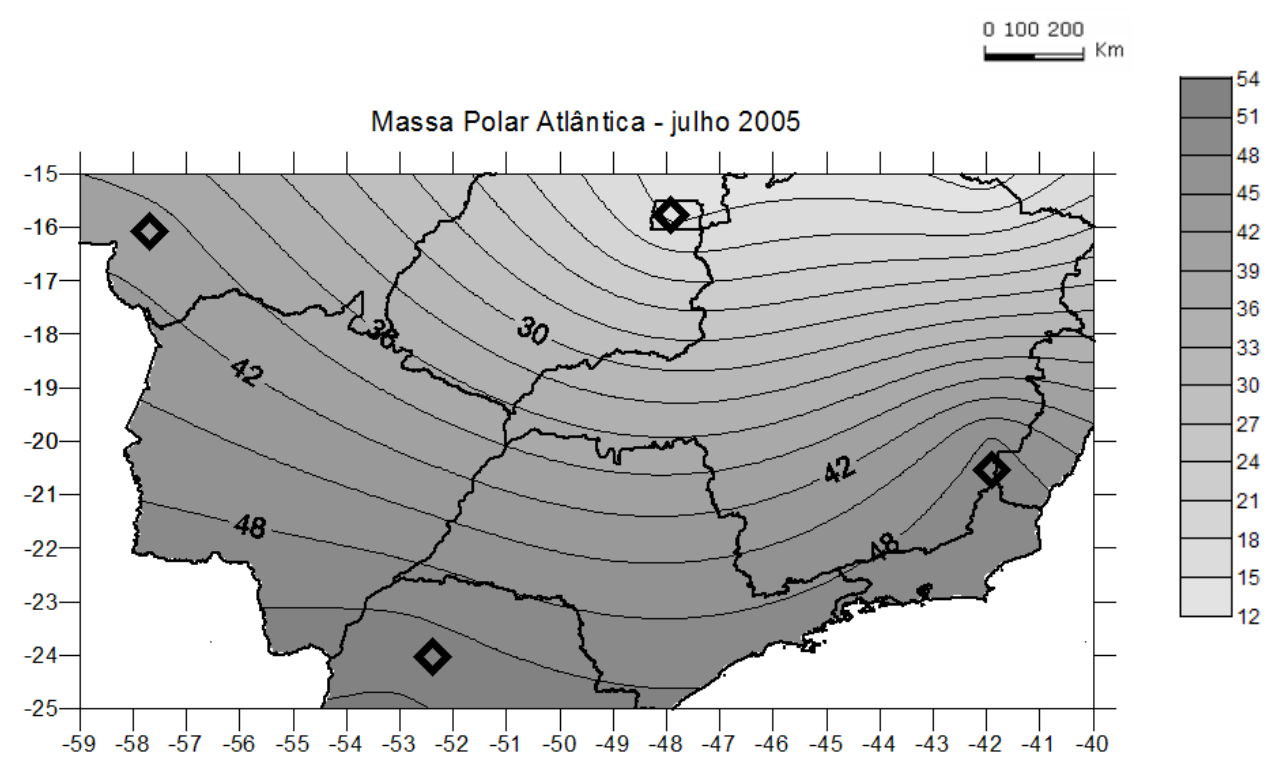

organização: Os autores.

No inverno, as frentes podem avançar até latitude inferior a - $15^{\circ}$ e pelo interior do continente. Os sistemas frontais raramente causam chuva ao norte do trópico.

As frentes no hemisfério sul geralmente se estendem na direção noroeste-sudeste. Ao longo delas formam-se ciclones, que se deslocam segundo a mesma direção, no seio dos quais existe acentuada mudança do vento, chuva forte, nuvens baixas e escuras, visibilidade reduzida, forte turbulência e possibilidade de formação de granizo e trovoadas. São seguidas por chuvas finas e contínuas, para finalmente, sob o domínio do anticiclone polar, o céu se tornar limpo com declínio acentuado da temperatura (Nimer, 1966, p. 236). 
Campo Mourão foi a região em que o SF mais atuou: 12,9\% do tempo cronológico, seguida por Caparaó, 6,5\%. A grande maioria dos sistemas frontais, ao avançar pelo interior, desloca-se para nordeste e, às vezes, atua até a região de Caparaó. Cáceres, dada a sua localização, apenas 4,3\% do tempo cronológico foi tomado pelo SF.

A passagem do sistema frontal, que antecede a chegada do ar polar propriamente dito, promove condições de forte instabilidade gerando chuvas antes, durante e depois da passagem da frente em várias áreas do território paulista (Monteiro, 1968, 1973; Tarifa, 1975) (Galvani; Azevedo, 2003, p. 1).

Para Brasilia, a porcentagem foi ínfima, 1,1\%, e se observou que é comum os sistemas apresentarem uma reflexão, ou seja, depois de atingirem baixas latitudes no interior do continente, há um retorno para latitudes já ultrapassadas e o deslocamento para o leste. A Figura 4 mostra a espacialização dos Sistemas Frontais no Centro-Sul do Brasil.

Armani e Galvani (2011) estudaram fluxos polares e o ritmo dos sistemas atmosféricos no nordeste do estado de São Paulo entre o inverno de 2008 e o outono de 2009 e verificaram que: A frequência da FPA nos meses de inverno aumentou de junho $(6,5 \%)$ até setembro (20\%), tendência seguida pelo SPA. Situação inversa a essa aconteceu com os sistemas tropicais, ou seja, a frequência deles diminuiu ao longo do inverno. (Armani; Galvani, 2011, p. 14)

Apesar de não ter sido abordado especificamente o estado de São Paulo, verifica-se que as porcentagens espacializadas pela região estão em conformidade com os resultados do Armani e Galvani (2011).

Figura 4 - Esboço do mapa da macrorregião Centro-Sul do Brasil. As isolinhas indicam a porcentagem da participação do SF para o mês de julho de 2005 (A equidistância das isolinhas é de 2\%)

0100200

Sistema Frontal - julho 2005
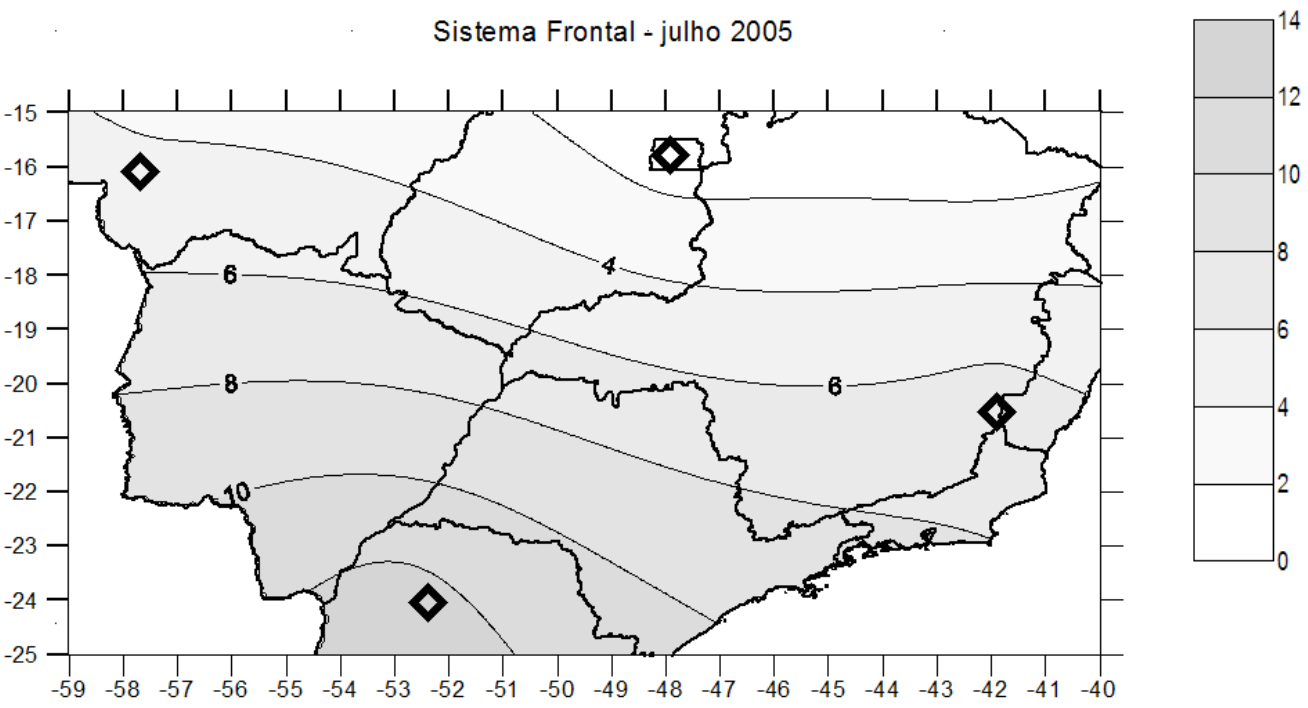

organização: Os autores. 
A mTc é um sistema de baixa pressão, e tem o seu centro de origem na região do Chaco, no Paraguai, em uma zona de alta temperatura e pouca umidade (Monteiro, 1968). Por essas razões, a mTc é uma massa de ar quente e de pouca umidade:

[...] Sua região de origem é a estreita zona baixa, quente e árida, a leste dos Andes e ao sul do trópico. É oriunda da frontólise na frente polar pacífica, cujos ciclones se movem para sudeste ocluindo depois de transpor os Andes, onde sofre efeito da dissecação adiabática. Esse fato ligado à grande insolação do solstício do verão deve contribuir para a elevação da temperatura e secura da massa. A depressão do Chaco se constitui assim em fonte da mTc (Nimer, 1979, p. 11).

Na estação do inverno, ela é inibida pelo avanço intenso e constante da mPa. Segundo Nimer (1966, p. 235), "Nesta época não existe a depressão continental, o que permite ao anticiclone do Atlântico, agora com pressão máxima, avançar sobre o continente [...]”. Mesmo diante dessas considerações, verificou-se a participação de 8,1\% para Campo Mourão, e 34,4\% para Cáceres. Em Brasilia e Caparaó, não foi constatada participação para o mês estudado (Figura 5).

\section{Figura 5 - Esboço do mapa da macrorregião Centro-Sul do Brasil. As isolinhas indicam a porcentagem da participação da mTc para o mês de julho de 2005}
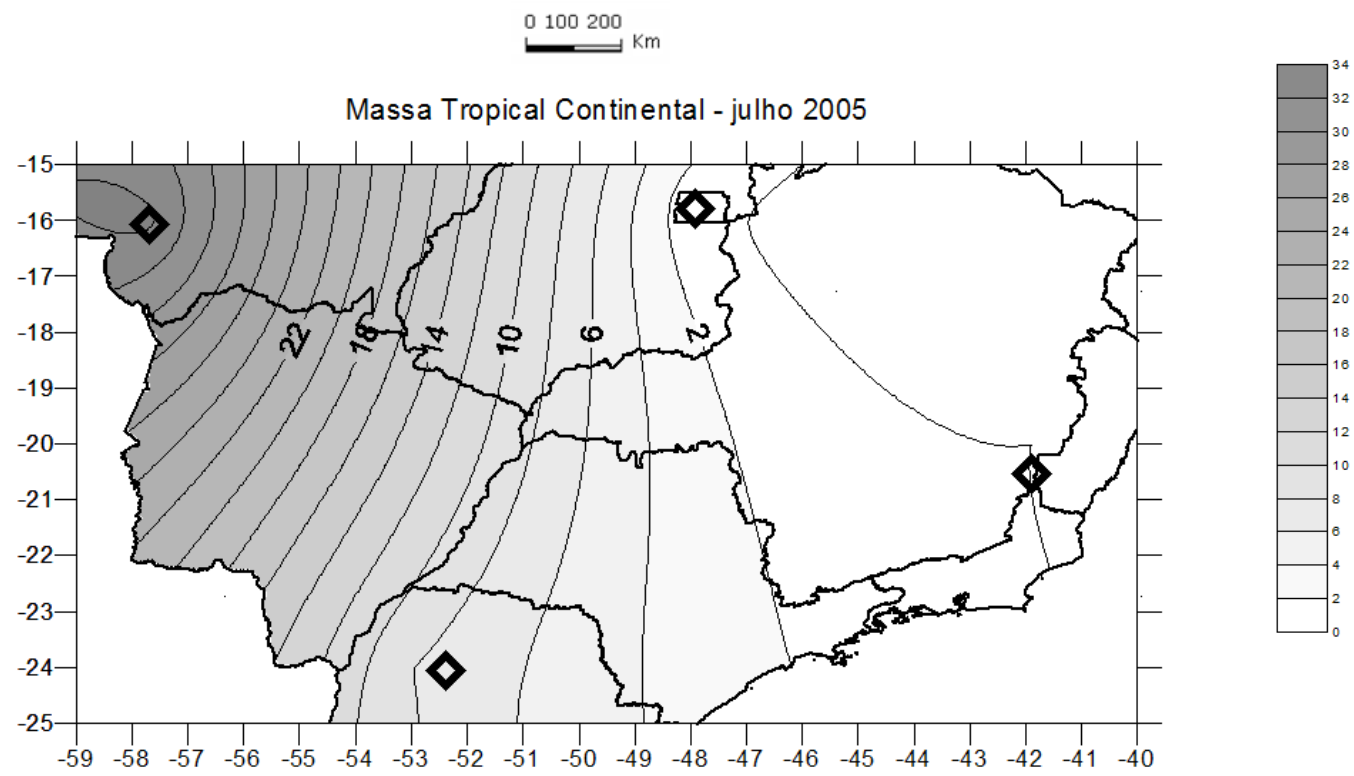

organização: Os autores.

\section{Análise rítmica}

O estado do tempo, para primeiro dia de julho, se configurou pelo domínio da mPa e da mTa. Sobre a região de Campo Mourão, atuava a mPa com 1.016 hPa (pressão lida na carta sinótica). Em Cáceres, também atuava a mPa, bem mais modificada e em confluência com a mTa; a pressão oscilava em 1.016 hPa. Em Brasilia, atuava a mTa; a pressão foi de 1.017 hPa. 
Caparaó apresentou uma configuração adversa. $\bigcirc$ SF, que se deslocou de sudoeste para nordeste nos últimos dias de junho, ainda atuava em Caparaó. Por isso, nessa localidade, atuaram o SF e a mTa.

Para o dia 2, com o deslocamento da mPa para o interior do Atlântico, a mTa se ampliou, e uma crista avançou para o interior. Da mesma forma, a mTc também se ampliou a partir do oeste. Constatou-se a atuação da mTc em Cáceres, e da mTa em Campo Mourão, Brasília, e parcialmente em Caparaó, que teve também a participação da mPa.

Para o dia 3, verificou-se a ampliação da mTc, a qual atuou em Cáceres e Campo Mourão, enquanto Brasília e Caparaó estiveram sob a mTa.

No dia 4, um SF avançou a partir do sul do Brasil. Mesmo com seu eixo pelo litoral, ele bordejou a região de Campo Mourão, sem causar chuva. Nesse mesmo dia, a mTa se ampliou, e uma crista avançou até Cáceres, que ficou sob a confluência da mTc com a mTa. Brasília e Caparaó permaneceram sob a atuação da $\mathrm{mTa}$.

A mPa, que avançou na retaguarda do SF, seguiu pelo interior do continente, impondo as suas características e assimilando as características das áreas. Por isso, ela se modificou e ganhou temperatura; as características anticiclonais e da pressão permaneceram. Ela avançou até a latitude de $-10^{\circ}$ no dia 7. A partir desse dia, gradativamente escoou para o Atlântico. $\bigcirc$ deslocamento se deu ao sul de Brasilia. Por isso, a capital do país permaneceu sob a atuação da mPa. Para Caparaó, esse sistema atuou a partir do dia 6 e permaneceu até o dia 11.

As chuvas registradas em Caparaó nos dias 8 e 10, certamente foram consequência da orografia, considerando que o SF se encontrava no interior do Atlântico e também porque a imagens de satélite no canal infravermelho mostram que não havia nebulosidade na região nesses dois dias (Figuras 6A e 6B).

\section{Figura 6 - Imagens de satélite Goes, canal infravermelho do Inpe/CPTEC}

\section{G-12 CH4 - A = 8 jul. 2005 e B = 10 jul. 2005}

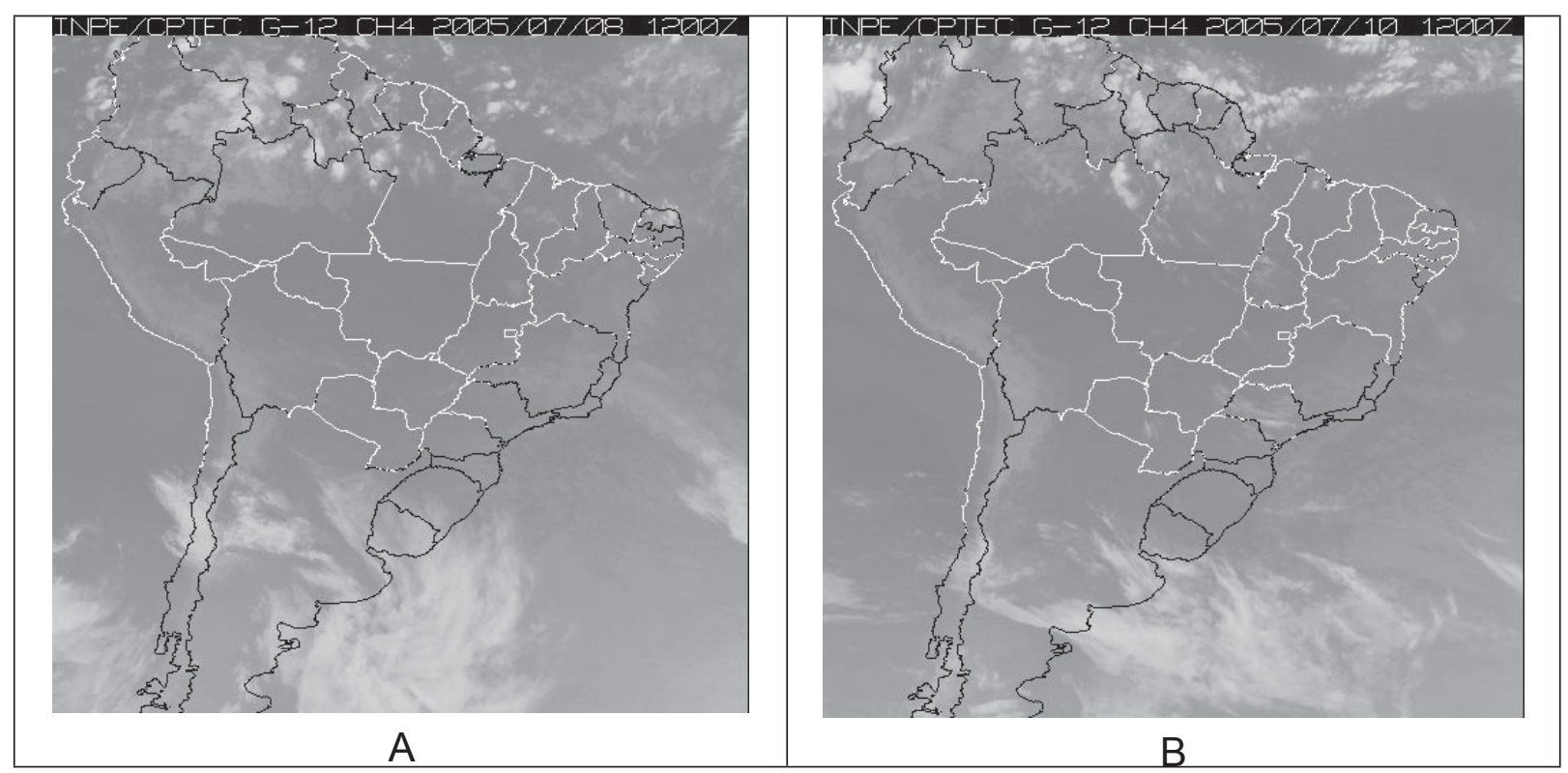

fonte: Inpe (2005). organização: Os autores. 
Na região de Campo Mourão, a mPa permaneceu até o dia 10, quando um novo SF avançou pelo litoral e uma nova $\mathrm{mPa}$ avançou pelo interior do continente. $\mathrm{O} S \mathrm{SF}$ afastou-se para o interior do Atlântico. A mPa atuou nos dias 12 e 13, e no dia 14, a região esteve sob a confluência da $\mathrm{mPa}$ com a $\mathrm{mT}$. A partir do dia 14 , a mPa foi substituída pela $\mathrm{mT}$. No dia 16, verificou-se a aproximação de um novo SF.

Em Cáceres, a mTa atuou até o dia 14. Com as modificações da mTa, a mTc se ampliou e passou a dominar o estado do tempo, que permaneceu até o dia 17. Para Brasília, a atuação da mTa foi mais persistente, embora nos dias 10 e 11, a mPa tenha bordejado a região. A partir do dia 12, a mTa atuou plenamente na região de Brasília por um período de 9 dias. Somente no dia 20, pequenas modificações no estado do tempo se manifestaram, consequência da aproximação de um SF. Houve um leve aquecimento, pequena queda na pressão e mudança na direção dos ventos. A partir do dia 21 , a mTa voltou a atuar.

Para Caparaó, a mPa voltou a atuar a partir do dia 13, e permaneceu impondo as suas características até o dia 16 , quando a mPa foi totalmente assimilada pela $\mathrm{mTa}$. A partir do dia 19, com a aproximação do SF, as condições do tempo foram alteradas, a temperatura se elevou e, no dia 20, foram registrados 5,6 mm de chuva.

O SF que atuou na região de Campo Mourão a partir do dia 16 permaneceu estacionário até o dia 19. Esse sistema avançou lentamente e, na latitude de -19\%, já se encontrava no litoral e em dissipação, enquanto a mPa que avançou na retaguarda, nos dias 17 e 18, atingiu a menor latitude e no interior do continente (-13० de lat., e -630 de long.). A partir do dia 18, ela se reflexa e escoa para sudeste. Por isso, ela não atuou na região de Brasilia, que permaneceu sob a influência da mTa.

Essa mPa atuou na região de Campo Mourão até o dia 21, quando foi modificada. A mTc se intensificou e se ampliou, a pressão teve uma forte queda sobre a região Sul do Brasil e evoluiu um ciclogênese. O SF associado ao ciclogênese atuou na região de Campo Mourão até o dia 25. Foram registradas chuvas nos dias 24, 25 e 26. Os volumes foram 7,9 $\mathrm{mm}, 6,0 \mathrm{~mm}$ e 6,3 $\mathrm{mm}$, respectivamente.

Enquanto o SF escoou para o oceano e pelo litoral, avançou até a latitude de -20॰, e lá se dissipou. A mPa avançou para o norte e atuou na região de Cáceres do dia 23 até o dia 27, quando foi substituída pela mTc. Mais uma vez, a mPa não atuou na região de Brasília, que permaneceu sob a atuação da mTa. Esse sistema frontal avançou pelo litoral e chegou à região de Caparaó no dia 26. As mudanças foram verificadas na temperatura, na pressão atmosférica, e foram registrados 2,4 mm de chuva.

Na região de Campo Mourão, depois da passagem do SF, a mPa atuou causando queda na temperatura, principalmente no período noturno. Essa mPa escoou para o Sudeste e, a partir do dia 27, foi integrada à mTa que atuou na região de Campo Mourão até o último dia do mês. 
Em Cáceres, a mPa se modificou e deu lugar à mTc, que atuou nos dias 27, 28 e 29. Com a ampliação da $\mathrm{mTa}$ a partir do leste, essa região também ficou sob a influência da circulação da mTa até o último dia do mês. Brasília, no entanto, ficou sob a confluência da mPa e mTa por um período de três dias, 28, 29 e 30, e encerrou o mês sob a circulação da mTa. Em Caparaó, a mPa atuou nos dias 27 e 28. Para o dia 29, a região esteve sob a confluência entre a mPa e mTa, que se ampliou e dominou o estado do tempo até o último dia do mês.

Para melhorar a interpretação da espacialização dos sistemas atmosféricos, foi confeccionado um gráfico com as porcentagens dos sistemas atmosféricos para as quatro localidades (Figura 7). Dessa forma, é possível visualizar a participação de cada sistema para cada uma das localidades analisadas.

As Figuras 8, 9, 10 e 11 foram confeccionadas com o programa RitmoAnalise. Toda a sequência descritiva da dinâmica climática para o mês de julho pode ser acompanhada na sequência das figuras, uma para cada localidade estudada.

A quantificação dos sistemas atmosféricos mostrou que os avanços da mPa pelo interior do continente foi superior ao ramo que avança pelo oceano.

Figura 7 - Porcentagem dos sistemas atmosféricos (SF, mPa, mTa, mTc, mEc e ZCAS) que atuaram no mês de julho de 2005 em Campo MourãoPR, Cáceres-MT, Brasília-DF e Caparaó-MG. A participação da mEc e da

\section{ZCAS foi zero.}

\section{Sistemas Atmosféricos - Julho 2005}

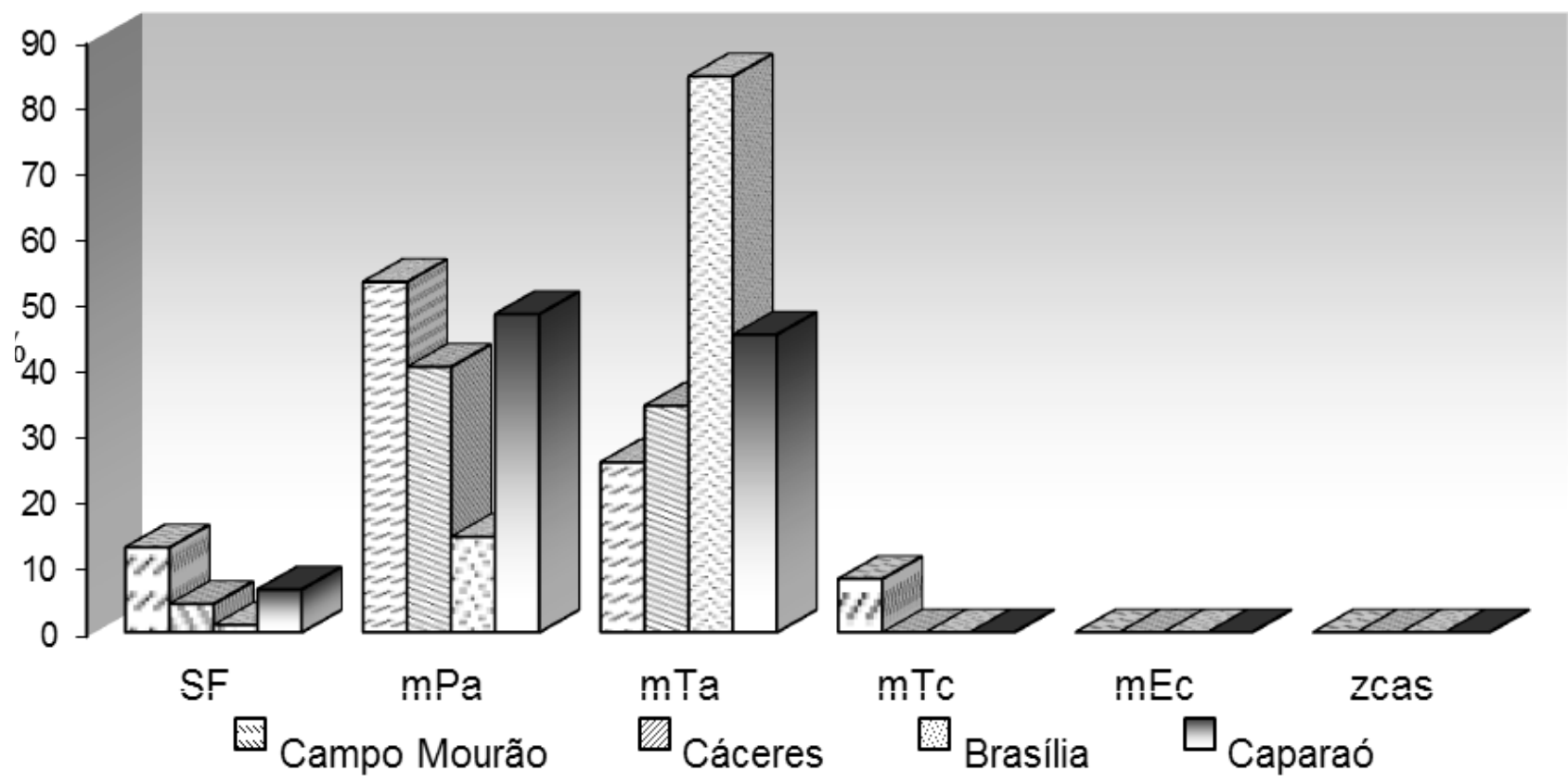


Figura 8 - Representação concomitante em unidades diárias da pressão atmosférica (12H TMG), temperatura máxima, mínima e a das $12 \mathrm{~h}$ TMG, umidade relativa ( $12 \mathrm{~h}$ TMG), precipitação $(\mathrm{mm})$, direção dos ventos e sistemas atmosféricos no mês de julho de 2005 para a Estação Climatológica de Campo Mourão-PR - INMET

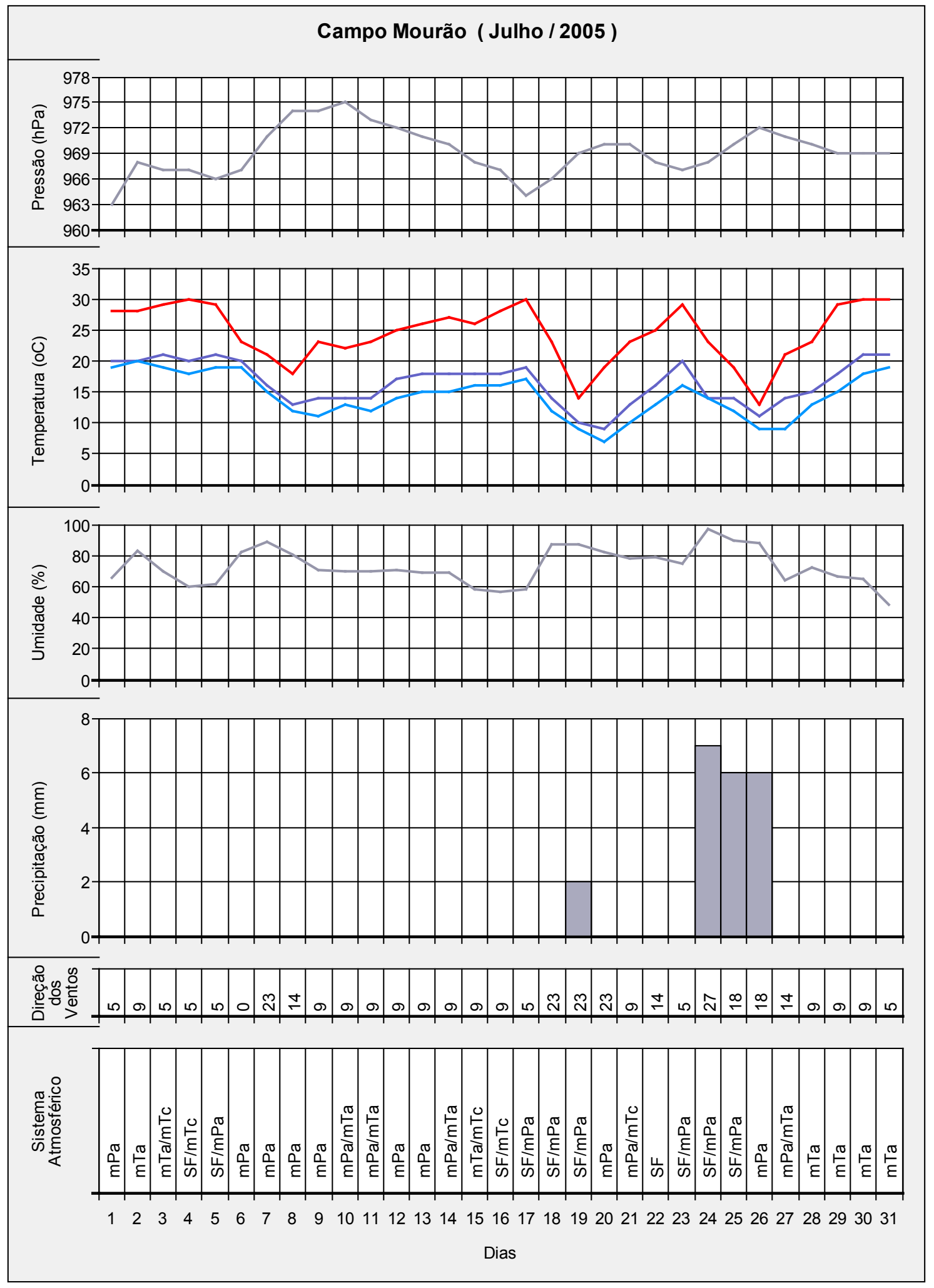


Figura 9 - Representação concomitante em unidades diárias da pressão atmosférica (12H TMG), temperatura máxima, mínima e das $12 \mathrm{~h}$ TMG, umidade relativa (12h TMG), precipitação $(\mathrm{mm})$, direção dos ventos e sistemas atmosféricos no mês de julho de 2005 para a Estação Climatológica de Cáceres-MT - INMET

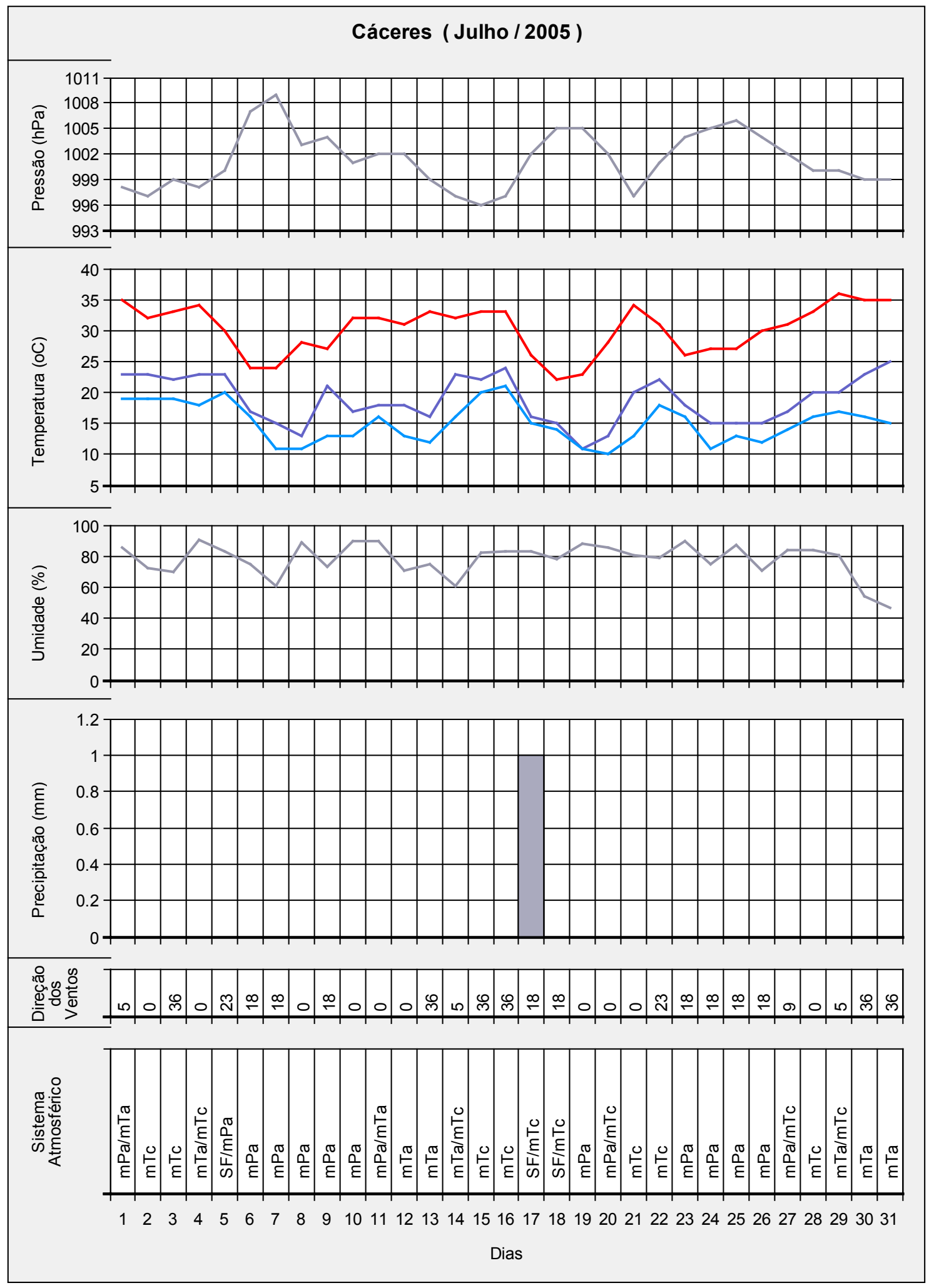

organização: Os autores. 
Figura 10 - Representação concomitante em unidades diárias da pressão atmosférica (12H TMG), temperatura máxima, mínima e das $12 \mathrm{~h}$ TMG, umidade relativa (12h TMG), precipitação $(\mathrm{mm})$, direção dos ventos e sistemas atmosféricos no mês de julho de 2005 para a Estação Climatológica de Brasília-DF - INMET

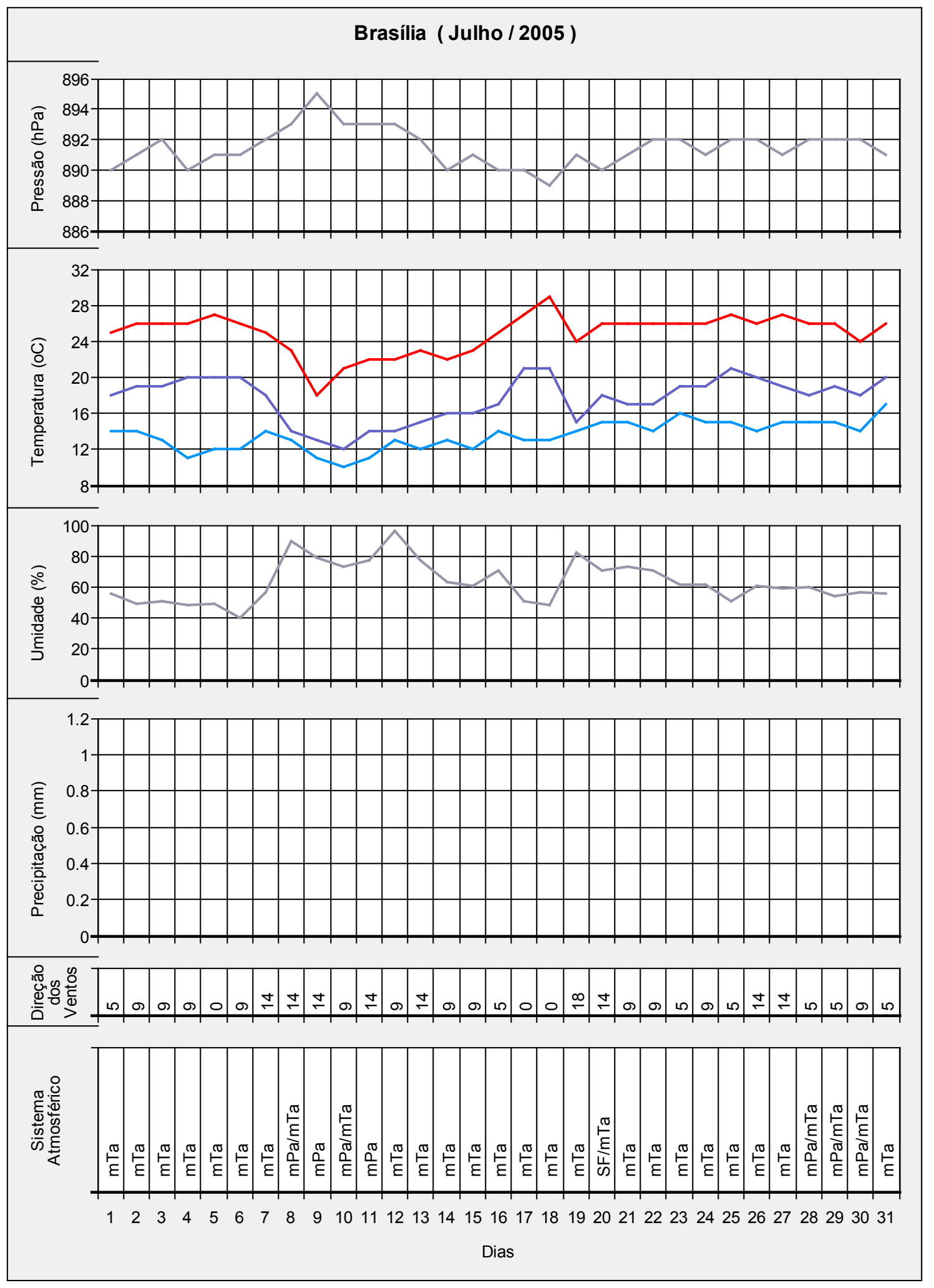


Figura 11 - Representação concomitante em unidades diárias da pressão atmosférica (12H TMG), temperatura máxima, mínima e das $12 \mathrm{~h}$ TMG, umidade relativa (12h TMG), precipitação $(\mathrm{mm})$, direção dos ventos e sistemas atmosféricos no mês de julho de 2005 para a Estação Climatológica de Caparaó-MG - INMET

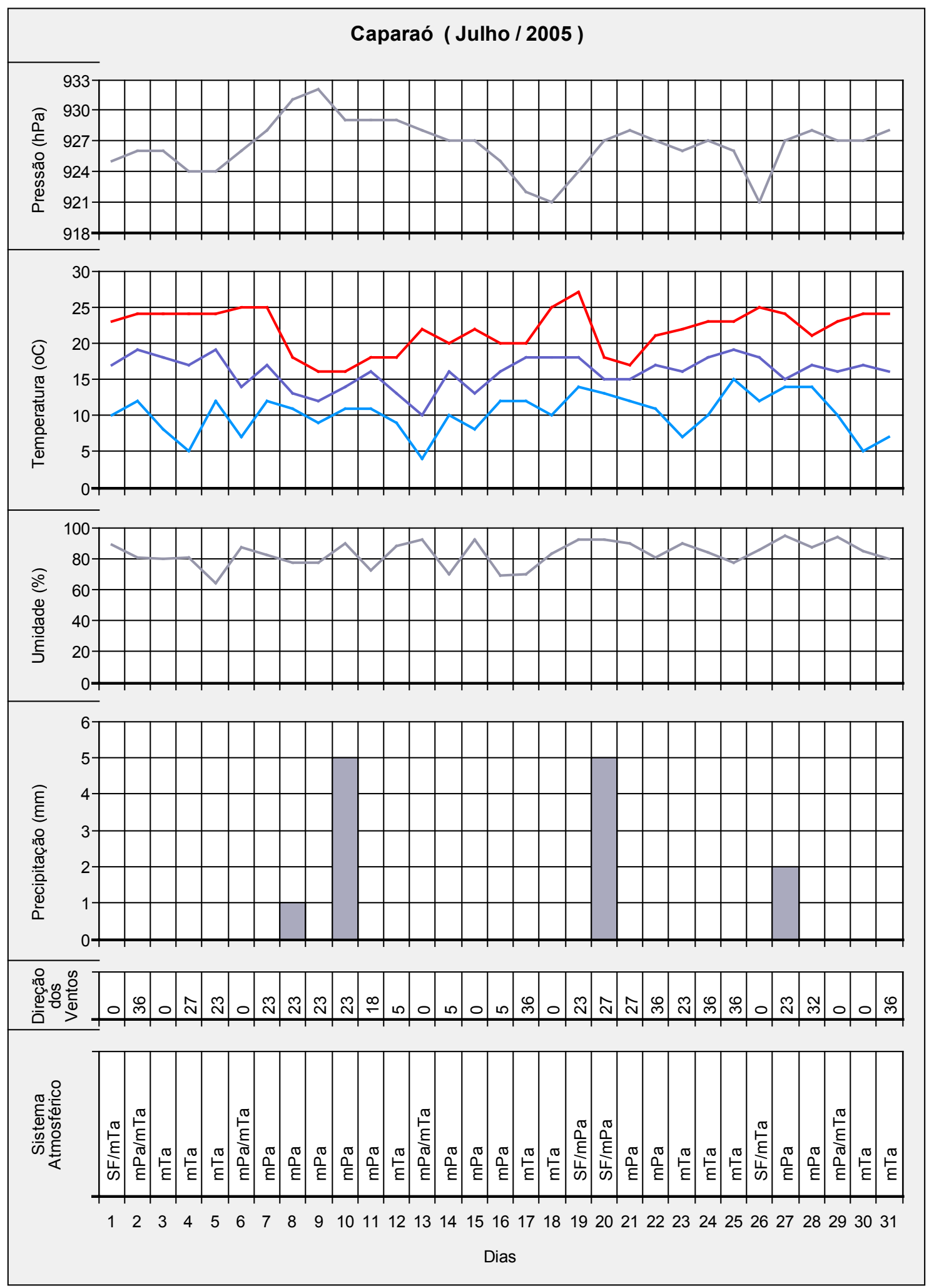

organização: Os autores. 


\section{Considerações finais}

A estação do inverno é dominada pelos sistemas de alta pressão, que, por natureza da circulação, são de baixa umidade relativa. Os sistemas de baixa pressão, quando atuam, apresentam-se modificados.

A mTa foi o principal sistema atmosférico. Ela proporciona dias ensolarados e com ampla amplitude térmica. Ela impõe e assimila as características das áreas por onde avança. Por essa razão, as mudanças no estado do tempo para o interior do Brasil são pouco significativas. Quando perde as características, a mTc se amplia.

A mPa foi o segundo sistema, considerando o tempo de atuação. Avança sobretudo pelo interior do continente e pode chegar ao sul da Amazônia. Verificou-se também que os eventos de maior pressão avançam mais rapidamente e atingem as menores latitudes. Quando isso ocorre, a onda de frio é mais intensa no sul do Brasil.

No período de 24 a 48 horas que antecede o avanço de um sistema frontal pelo interior do sul do Brasil, a mTc se amplia e desloca-se para o leste e, às vezes, atua até o litoral da região.

\section{Referências}

ARMANI, G.; GALVANI, E. Fluxos polares e o ritmo dos sistemas atmosféricos no nordeste do estado de São Paulo. Sociedade E Natureza, Uberlândia, v. 23, n. 1, p. 7-22, abr. 2011. Disponível em: <http://www.redalyc.org/articulo.oa?id=321327201002>. Acesso em: 20 abr. 2013.

BISCARO, G. A. Meteorologia agrícola básica. Cassilândia, MS: Unigraf, 2007.

BORSATO, V. A. A dinâmica atmosférica na vertente oriental da bacia do alto rio Paraná e a gênese das chuvas. Acta Scientiarum. Agronomy, v. 30, n. 2, p. 221-229, 2008.

- A participação dos sistemas atmosféricos atuantes na bacia do Alto Rio Paraná no período de 1980 a 2003. Tese (Doutorado em CiÊncias Ambientais) - Núcleo de Pesquisas em Limnologia, Ictiologia e Aquicultura - Nupelia, Universidade Estadual de Maringá, Maringá, 2006.

; MENDONÇA, F. A. A PARTICIPAÇÃO DA MASSA TROPICAL ATLÂNTICA NO ESTADO DO tempo no Centro-Sul do Brasil. Revista Geonorte, Manaus, v. 1, n. 5, p. 293-304, 2012. Número especial.

CAMARGO, R.; FREDIANI, M. E. B. Frentes e frontogêneses: meteorologia sinótica. In: SiMPÓSIO DE ESTUdOS URBANOS, 2., 2013, Campos Mourão, PR. Anais... Campos Mourão: Universidade Estadual do ParanÁ, 2013. Disponível EM: <HTtp:// WWW.MASTER.IAG.USP.BR/ENSINO/SINOTICA/AULA09/AULA09.HTML>. ACESSO EM: 24 MAR. 2014.

FERREIRA, C. C. Ciclogêneses e ciclones extratropicais na região Sul-Sudeste do Brasil e suas influências no tempo. São Paulo: INPE-4812-TDL/359, 1989. 
GALVANI, E.; AZEVEDO, T. R. A frente POLAR ATLÂNTICA E AS CARACTERÍSTICAS DE TEMPO ASSOCIADAS: ESTUDO DE CASO. IN: SIMPÓSIO BRASILEIRO DE GEOGRAFIA FÍSICA APLICADA, 10., 2003, RIO DE JANeIRO. Anais... Rio de Janeiro, 2003. Disponível em: <http://www.geografia.fflch.usp.br/graduacao/apoio/Apoio/Apoio_Emerson/ SBGFA2003.PDF>. Acesso em: 10 dez. 2015.

INPE. INSTITUTO NACIONAL DE PESQUISAS ESPACIAIS. Divisão de Satélites e Sistemas Ambientais. Banco de dados de imagens, 2005. Disponível em: $<$ http://satelite.cptec.inpe.br/acervo/goes.formulario.logic >. Acesso em: $10 \mathrm{dez}$. 2015.

MONTEIRO, C. A. F. A dinâmica climática e as chuvas no estado de São Paulo: estudo em forma de Atlas. São Paulo: IGEOG/USP, 1973.

Análise rítmica em climatologia: problemas da atualidade climática em São Paulo e achegas para um programa de trabalho. Climatologia, São Paulo, n. 1, 1971.

Clima. In: Geografia do Brasil: Grande Região Sul. Rio de Janeiro: IBGE, v. 4, n. 1, p. 114-166, 1968.

MUSK, L. Weather systems. Cambridge: Cambridge University Press, 1988.

NIMER, E. Climatologia do Brasil. Rio de Janeiro: IBGE, 1979.

Climatologia da região Sul do Brasil. Revista Brasileira de Geografia, Rio de Janeiro: IBGE, v. 33, n. 4, p. 3-65, 1971.

Circulação atmosférica do Brasil (comentários): contribuição ao estudo da climatologia do Brasil. Revista Brasileira de Geografia, Rio de Janeiro: IBGE, p. 232-250, set. 1966.

OLIVEIRA, L. L.; VIANELLO, R. L.; FERREIRA, N. J. Meteorologia fundamental. Erechim: Fapes, 2001.

PADILHA, C. K. Estagnação de massa de ar quente e seco sobre a região Central do Brasil, São José dos Campos: INPE, 2008.

PÉDELABORDE, P. Introduction à l'étude scientfique du climat. Paris: Sedes, 1970. SANT' ANNA NETO, J. L. Ritmo climático e a gênese das chuvas na zona costeira paulista. Dissertação (Mestrado em Geografia) - Faculdade de Filosofia, Letras e Ciências Humanas, Universidade de São Paulo, São Paulo, 1990.

SERRA, A. B.; RATISBONNA, L. As ondas de frio da Bacia Amazônica. Boletim de Geografia, v. 3, n. 26, p. 172-206, 1945.

SORRE, M. Le Climat. In: Les fondements de la geographie humaine. Paris: Armand Colin, 1951. p. 13-43.

TARIFA, J. R. Fluxos polares e as chuvas de primavera/verão no estado de São Paulo. Tese (Doutorado em Geografia) - Faculdade de Filosofia, Letras e Ciências Humanas, Universidade de São Paulo, São Paulo, 1975. 
VAREJÃO-SILVA, M. A. Meteorologia e climatologia. Brasilia, DF: Instituto Nacional de Meteorologia Brasilia, 2000.

VIANELLO, R. L. Meteorologia básica e aplicações. Viçosa, MG: Editora da UFV, 2000. 